\title{
ELECTION DEPOSIT AND DEMOCRACY IN DEVELOPING COUNTRIES: A Comparative Overview in Selected Southern African Development Community Countries
}

\author{
Mbuzeni Johnson Mathenjwa \\ Mbuzeni Mathenjwa is an attorney of the High Court of South Africa \\ and Associate Professor of Law, Department of Public, Constitutional and \\ International Law, University of South Africa, Pretoria \\ e-mail: mathemj1@unisa.ac.za
}

\begin{abstract}
After their independence most African countries adopted constitutions that enshrine democracy and the right to vote and stand for public office. These political rights are important tools for ensuring democracy as they enable citizens to participate in both constituting and having a say in their own government. Despite entrenching these rights in their constitutions, many African countries went further and adopted laws requiring citizens who wish to participate in elections to pay an election deposit fee. Given the fact that most developing countries in Africa experience fairly widespread poverty, many potential candidates may not be able to afford the election deposit fee. Accordingly, the election deposit fee may well hinder the cause of democracy by excluding citizens from exercising their political rights. This paper discusses the effect of an election deposit fee on democracy in developing countries in Africa. The discussion is limited to selected countries in the Southern African Development Community.
\end{abstract}

Keywords: election, deposit, democracy, vote, constitutionalism

\section{INTRODUCTION}

Most African countries adopted constitutions that enshrined democracy and guaranteed political rights to their citizens. ${ }^{1}$

1 See section 19 of the Constitution of the Republic of South Africa, 1996; article 1 of the Constitution of the Republic of Mozambique, 2004; article 1 of the Constitution of the Republic of Namibia, 1990 and section 3 of the Constitution of the Republic of Zimbabwe, 2013. 
Furthermore, these countries adopted laws aimed at implementing the provisions of their constitutions regarding the exercise of political rights. These laws prescribed the conditions and procedures for accessing the rights which, among other things, included the requirement for an election deposit fee to be paid by a candidate or political party wanting to participate in elections. Consequently, those candidates and political parties who could not afford the election deposit fee were excluded from exercising their political right to participate in the election.

This study discusses the effect of the election deposit on the attainment of democracy in developing countries. This it does by conducting a comparative overview of Southern African Development Community (SADC) countries with regard to enshrining democracy in their constitutions, the environment in which elections are held, and the laws that regulate the participation of candidates and political parties in elections. As background to the main discussion, the concept of democracy and the right to participate in elections and stand for public office is discussed. Finally, a conclusion is drawn regarding the effect of an election deposit fee on the achievement of democracy.

\section{THE CONSTITUTIONALISATION OF DEMOCRACY}

The concept of democracy has a contested meaning, with different writers having their own definitions and understanding of the concept (De Vos 2014). One of the most fundamental values of democracy is that of self-government, that is the freedom of individual citizens to rule over themselves through a concerted collective process (Lindberg 2006). Two of the institutional conditions of democracy are the election of representatives by universal adult suffrage to institutions that allow those representatives to govern; and the free entry of citizens to candidacy for electoral office (Greenberg 1993). The core of democratic self-government is thus representative democracy whereby citizens participate in the governance of their own affairs through their elected representatives.

Given the history of colonialism and apartheid on the African continent, most African countries included constitutional democracy as one of their core founding values. This sent a positive message that after achieving liberation, African countries would not revert to an era in which some people were excluded from enjoying certain benefits or were discriminated against because of their race, gender, religion or other features. In this regard, the Namibian Constitution provides that the Republic of Namibia is established as a secular and democratic state founded upon the principles of democracy [art. 1(1)]. In Zimbabwe, the Preamble to the Constitution provides that the people of Zimbabwe commit themselves to upholding the principles of democracy and good governance. Furthermore, Zimbabwe's Constitution is founded on respect for the principles 
of good governance which include a multi-party democratic political system [sec. 3 (2) (a)].

The Mozambican Constitution states that the Republic of Mozambique is an independent, democratic state of social justice (art. 1). The Republic of Mozambique is a state governed by the rule of law based on the pluralism of expression and democratic political organisation [art. 3.(f)]. In Zambia, the people commit themselves to upholding the principles of democracy and good governance and resolve that Zambia shall remain a multi-party and democratic state. Their Constitution proclaims the Republic of Zambia as a multi-party democratic state [sec. 4 (3)]. In addition, democracy is one of the national values and principles upon which the Republic of Zambia is founded [sec. 8 (c)]. In Angola, the Constitution of Angola declares Angola to be a state whose primary objective shall be to build free, just, and democratic equality and social progress (art.1). In South Africa, the Constitution proclaims South Africa to be a democratic state founded on the values of a multi-party system of democratic government to ensure accountability, responsiveness and openness [sec. 1 (d)].

The question needs to be posed as to the effect of constitutionalising democracy. A constitution is a founding document from which the authority of the state is derived. It regulates and limits the exercise of power by the state (De Vos 2014). According to Mueller (1996, p. 43), the effect of the constitution in democratising a country is manifested when the constitution is consciously chosen and designed by the citizens. When these constitutions are regarded by both citizens and government as being supreme law, they place real limitations on what the citizens and government can do. A country therefore takes a positive step in democratising itself by entrenching democracy in its constitution, if such a constitution is chosen by the citizens themselves. Such a constitution ought to be a binding declaration that democracy will prevail and will be realised. Accordingly, the conclusion can be drawn that these states are binding themselves to being constitutional democracies. A constitutional democracy is defined as a system of government in which decisions are made in terms of the constitution (De Vos 2014).

Democracy is further entrenched by the declaration by all SADC countries that their constitutions are the supreme laws of their countries. Zambians proclaim their Constitution to be the supreme law of that nation [art. 1 (1)]; the Constitution of Namibia provides that the Constitution shall be the supreme law of Namibia [art. 1 (6)]; in Zimbabwe the Constitution is the supreme law, and any law, practice or conduct inconsistent with the Constitution is invalid (sec. 2); the Constitution of Mozambique provides that the state is subordinate to the Constitution, and the Constitution shall prevail over all other rules of the legal order [art. 2 (3)]; in Angola the Constitution is the supreme law of that country [art. 6 (1)]; and in South Africa, 'the Constitution is the supreme law of the Republic; law or conduct 
inconsistent with it is invalid, and the obligations imposed by it must be fulfilled' (sec. 2). Thus, given the supremacy of the constitution in SADC, no law or conduct should undo democracy or impinge on the citizens' rights to stand for election. Accordingly, SADC countries are obliged to ensure that conditions are conducive to the prevailing of democracy.

\section{THE RIGHT TO CONTEST ELECTIONS}

Apart from constitutionalising democracy, most SADC countries guarantee their citizens the right to stand for public or political office. In Namibia, every citizen who has reached twenty-one years of age has the right to be elected to public office [art. 17 (2)]. The Zambian Constitution provides that the electoral systems for the election of president, members of Parliament or councillors, should ensure that citizens are free to exercise their political rights [art. 45 (1)]. A citizen who has attained the age of eighteen years is entitled to register as a voter and to vote in an election, and a political party has the right to sponsor a candidate for election or nomination to a state office. In Zimbabwe every citizen has the right to regular election to elective public office, and every citizen who has attained eighteen years of age has the right to stand for election for public office [sec. 67 (1) \& (3)]. In Mozambique, citizens are entitled to exercise political power through the election of their representatives [art. 73]. In Angola every citizen has the right to stand for public office [art. 53 (1)]. In regulating this right, the law may determine only the ineligibilities required to guarantee electors the freedom of choice. Every citizen who has attained the age of eighteen years has the right to stand for election for any state or local authority [art. 54 (1)].

In South Africa, every citizen has the right to make political choices, and every adult citizen has the right to stand for public office and, if elected, to hold office [sec. 19 (3)]. The right to stand for public office is another aspect of the political rights provided for in the Bill of Rights in the Constitution. Accordingly, the right to vote, to participate in an election as a candidate and to seek public office, are protected by the Constitution. The right of the citizens to have free and fair elections and to stand for public office was prompted by the Constitutional Court case of Khan V Electoral Commission [2016 (2) SA 388 (CC)]. The applicants, who were independent ward candidates contesting by-elections at Tlokwe Local Municipality, challenged the outcome of the elections on the grounds that some people who voted in the by-elections were not resident in the voting districts where they voted and that the voters' roll did not contain the physical addresses of the voters. The failure of the Independent Electoral Commission (IEC) to provide candidates with copies of a voters' roll which included the addresses of the registered voters was contrary to the provisions of the Municipal Electoral 
Act. As a result, the court found that the elections conducted at Tlokwe Local Municipality had not been free and fair [para. 126]. The process of election to public office is of cardinal importance for achieving democracy. This view is reinforced by the Kham judgment in demonstrating that the mere existence of the right to participate in elections through voting or standing for public office, without the existence of conducive conditions for its effectiveness, does not contribute positively to the democratisation of government.

Elections are primarily about the right of citizens to participate in and to have their say in government. The right to vote and to stand for public office is linked to free and fair elections. While there is no universal definition of free and fair elections the expression 'free and fair elections' was explained in the Kham case [para. 86]. This highlighted both the freedom to participate in the electoral process and also the ability of the candidates to compete with one another on relatively equal terms. For example, the denial of facilities for conducting meetings and the non-availability of voting stations within the reach of the citizens who are entitled to vote, could prevent an election from being categorised as free and fair. Free and fair elections are those in which all citizens are entitled to stand for election and to be treated in the same manner. The importance of political rights cannot be overlooked in Africa as many people struggled for, fought for and lost their lives to secure these rights for all citizens. In the dissenting judgment in the Constitutional Court case of Electoral Commission v Hlophe [2016 (5) SA 1 (CC) para. 141], Judge Jafta defined political rights by stating that: 'These rights constitute a cornerstone of our democratic order and are pivotal to the creation and legitimacy of a government formed after elections. Without them democracy itself cannot exist'. Accordingly, for a government to be based on the will of the people and to be the government of the people, citizens should enjoy political rights without any hindrances. The electoral laws that regulate participation in elections by the citizens should thus not exclude citizens from the enjoyment of these rights.

\section{THE OPERATING ENVIRONMENT FOR ELECTIONS}

As stated above, most SADC countries enshrine political rights and democracy in their constitutions. Each SADC country has its own electoral laws that prescribe the qualifications and requirements for a candidate who wishes to stand for election to the office of president, or for the national and provincial legislatures or local authority. The question arises as to whether the environment under which elections are held is conducive for attaining democracy and exercising political rights in these countries. Thus the legal framework and environment in which elections are held in SADC countries is assessed in order to establish whether these countries adhere to the principles of democracy and the law. 


\section{Zambia}

The Electoral Institute for Sustainable Democracy in Africa (EISA) reports that conditions in which elections took place in Zambia were largely peaceful (EISA 2008). In Zambia electoral laws prescribe that a deposit be paid by any candidate wanting to contest either the presidential or National Assembly election [sec. 21 (1) (b) and 23 of the Electoral Act].

As a result the Electoral Commission of Zambia (ECZ) prescribed what fees were to be paid for contesting elections for the office of the president, National Assembly and mayoral office in local government. According to Paul Shalala, political analyst and reporter for the Zambia National Broadcasting Corporation (2016), the ECZ increased the election fee by more than 100\% for the 2016 presidential election. As a result of the requirement for an election deposit in Zambia, reports indicate that only five of the forty-six registered political parties paid the presidential nomination fees which were fixed at K75,000 (Daily Nation 2016). Consequently, all those political parties who failed to pay the deposit were disqualified from standing in the elections and opposition parties thus disqualified were enraged (Zambia Reports 2016).

Allan Sakala, an independent candidate for Munali constituency in Lusaka, threatened to take the ECZ to court over the high nomination fees (Africa Fight Now 2016). He also wrote that these fees make politics and leadership the preserve of the rich and the corrupt in Zambia. Several other candidates similarly disqualified from standing for the office of the president argued that hiking nomination fees was discriminatory because it barred rural communities from participating in the governance system and marginalised poor in the electoral system and process.

\section{Namibia}

Conditions under which elections are held in Namibia are fairly satisfactory (SADC Observer Mission 2014). The Namibia Electoral Act of 2014 states that in the case of a candidate nominated by a political party for the election of president, the nomination form must be accompanied by a receipt indicting that an amount of N\$2000 (Namibian dollar, which is equivalent to the South African rand) has been deposited with the state revenue fund by the party. In the case of an independent candidate, the nomination form must be accompanied by a receipt showing that an amount of $\mathrm{N} \$ 10000$ has been deposited with the state revenue fund by the candidate [sec. 73 (4) (c )-(d)]. The deposit is forfeited if a candidate records fewer than $10 \%$ of the overall total votes cast in that specific presidential election. Consequently all but two of the political parties that took part in the presidential election lost their deposit of $\mathrm{N} \$ 10000$ after failing to garner sufficient votes (Maletsky 2009). 


\section{Zimbabwe}

Although the Zimbabwean Constitution enshrines both democracy and the right to vote and to stand for public office, the country has failed to adhere to the spirit of the Constitution. A high incidence of violence and vote-rigging during elections has become the norm. This was evident in the 2008 presidential elections which were characterised by violence, included several arrests of the leader of the opposition, Morgan Tsivangirai (EISA 2008).

The 2013 general elections were perceived to be free and fair because they were not tainted by any visible incidence of violence and intimidation. However, according to Southall \& Van Zyl Slabbert (2013, p. 142) the 2013 elections were another case of election rigging. The authors refer to other serious issues which demonstrate the failure of the Zimbabwe African Union Patriotic Front (Zanu$\mathrm{PF}$ ) government to uphold the rule of law. For these reasons, Southall \& Van Zyl Slabbert (2013, p. 139) argue that although the 2013 Zimbabwe elections were not characterised by violence, the governing party of President Mugabe implemented numerous dubious measures devised to skew the vote. This view is reinforced by Masunungure (2013, p. 100) who argues that although the 2013 elections in Zimbabwe appeared to be free and fair the Zanu-PF manipulated the process. According to Masunungure (2013, p. 103), in an abuse of the public media a day before the election Zanu-PF invented a public survey indicating a thrashing victory by President Mugabe's Zanu-PF over Mr Tsvangirai of MDC-T. In this regard Zanu-PF went the extra mile not so much to win but to publicise their win as credible and inevitable

In a practical sense, the right of Zimbabwean citizens to vote and to stand for public election was affected when President Mugabe failed to proclaim the 2013 election date before the end of the life of the Parliament. In the unreported case of Mawarire v Mugabe (CCZ1/13), the court held that the failure by the president to proclaim an election date before the expiry of the life of Parliament was contrary to the principle of constitutionalism and violated the citizen's political right to vote and to stand for public office as protected by para. 10 of the Constitution.

In Zimbabwe, the Electoral Act of 2004 [sec. 46-47] provides that the nomination of candidates for election as members of Parliament shall be accompanied by a deposit of such a sum as may be prescribed which will be deposited with the constituency registrar, by, or on behalf of, the person nominated. If the candidate records less than a fifth of the votes cast for the successful candidate, the sum deposited by the unsuccessful candidate shall be forfeited.

Despite the legal framework that regulates the holding of elections in Zimbabwe, it is arguable that the country might not be adhering to the principles of democracy and rule of law. This conclusion is supported by the history of election rigging, intimidation, violence waged against opposition parties, and 
the failure of the president to comply with the prescripts of the law, so offending the rights of citizens to participate in elections.

\section{Mozambique}

After gaining independence in 1975, Mozambique was plagued by civil war (EISA Observer Mission 2014). However, it is noted that since the end of the civil war the political environment has been relatively conducive to free and fair elections.

The Constitution of Mozambique delegates the regulation of electoral procedure to law. The Electoral Law of Mozambique of 2004 [art. 123,125,141,142 \&144] regulates nomination for both the post of president and members of the National Assembly (referred to as deputies of the Assembly) but makes no mention of a nomination deposit fee. In order to stand for election a candidate nominated for presidential office must be endorsed by 10000 citizens who are voters (EISA 2010). Accordingly, an election deposit is not required for contesting elections in that country. Furthermore, the Mozambique electoral system makes provision for election campaigns for both the presidential and National Assembly elections to be funded. Pursuant to this arrangement, the state allocates electoral campaign funds equally to all the participants who contest the elections (EISA 2014).

\section{Angola}

After independence Angola was riven by a civil war which ended in 2002. The history of elections in Angola shows that the political climate has evolved from a post-conflict situation, characterised by violence and allegations of election rigging, to one of normality (EISA 2012).

Angola is one of the SADC countries to fund the election campaigns of political parties. The amount of funding to be provided for each party and coalition in an election year is announced by presidential decree (EISA 2012). No election deposit is required for candidates for either the office of the president or the National Assembly in Angola. Articles 106 and 111 of the Constitution of Angola, which provide for the appointment of the president and members of the National Assembly, make no mention of an election deposit fee. In addition the Angola Electoral Law of 2004, which regulates the qualifications of candidates for nomination to the office of president and to the National Assembly, makes no mention of an election deposit fee. The law requires that the candidates proposed for election for the national constituency must be supported by between 5000 to 5500 voters, and by 500 to 550 voters for the provincial constituencies [art. 62(2)].

\section{South Africa}

Many observers perceive South Africa as a country riven by excessive and widespread violence, including political violence. According to Schonteich and 
Louw (2009), recorded criminal violence has increased consistently since 1994 unlike overall recorded crime levels which decreased slightly in 1995-1996. This view is reinforced by Dovey $(2009$, p. 50) who argues that when South Africa became a democratic republic in 1994, it faced a decrease in political violence but an escalation in violent crimes and this has led to South Africa's reputation as a crime capital. After the first democratic election on 27 April 1994, political violence throughout the country decreased greatly (Dovey 2009). It is evident from the reports of EISA for the 2014 national and provincial elections and 2016 local government elections that conditions in South Africa are conducive to free and fair elections (EISA 2014, 2016).

In South Africa, a political party may contest the national and provincial elections if that party is registered and has submitted a list of candidates [sec. 26 (a)-(b) of the Electoral Act of 1998]. The list of candidates submitted to the chief electoral officer must be accompanied by the prescribed deposit. The amount of the deposit is prescribed by the Independent Electoral Commission (IEC) with the proviso that the amount of the deposit by a registered party contesting an election of a provincial legislature must be less than the amount for contesting an election of the National Assembly. In local government candidates are elected through the dual electoral system of both the constituency and proportional representation. Norris (1997, pp. 303-305) states that in a constituency system, voters cast a single ballot for one candidate in the constituency, and the candidate with the largest share of the vote in each seat is returned to office. Under the proportional representation system, the seats in a constituency are divided according to the number of vote cast for the party list. Thus, in the dual system half of the seats are elected direct from the constituency and half are elected from party lists allocated by proportional representation.

At local government level the Local Government: Municipal Electoral Act of 2000 [sec. 13 (1)] provides that only registered parties may contest an election by submitting a list containing the names of candidates to stand for the party's proportional representation to the council. In addition, they may also nominate a ward candidate as a representative of the political party in that ward. The parties are required to submit a party list and a deposit equal to a prescribed amount to the office of the IEC local representatives not later than a date stated in the timetable for the election. A person may be nominated to contest an election in a ward either by a registered party or by an ordinary person who is a registered voter on the municipal voter's role. Ward candidates are also required to pay a prescribed deposit. An independent ward candidate needs to pay the prescribed deposit, and the nomination must also be supported by at least 50 voters on the voter's roll for any voting district in the ward. 
Concern has been raised about the payment of an election deposit and the issue has been contested in the courts. In the Constitutional Court judgment of African Christian Democratic Party v Electoral Commission [2006 (3) SA 305 (CC)], the applicant - the African Christian Democratic Party (ACDP) - lodged a party list and nominated ward candidates for election to the Cape Town Metropolitan Council at the Cape Town offices of the Independent Electoral Commission, but it omitted to pay the deposit fee at the Cape Town office. Furthermore, the applicant made a bulk payment by way of a bank guaranteed cheque to the national office of the IEC in respect of a range of municipalities, but the Cape Town metropolitan area was erroneously not included in the list of municipalities. There was, however, enough surplus money in the bulk payment to cover the deposit for the Cape Town candidates. When the IEC refused to allocate the surplus funds as a deposit for the Cape Town metropolitan area, the applicant approached the court for relief. In interpreting the provisions of the Electoral Act relative to the payment of a deposit, the court held that the Act must be construed in the light of the foundational values of the Constitution. This states that the Republic of South Africa is a democratic state founded on the values of universal adult suffrage, a national common voters' roll, regular elections and a multi-party system of democratic government to ensure accountability, responsiveness and openness' (para. 21). These fundamental values require both the courts and the IEC, when interpreting the provisions of the Electoral Act, to promote enfranchisement rather than disenfranchisement and participation rather than exclusion. The court found that the IEC had erred in concluding that the applicant had not complied with the provisions of the Electoral Act on the payment of the deposit (para. 35). This judgment emphasizes the value of political rights in that the legislation regulating these rights should be interpreted in a manner to promote the enjoyment rather than the denial of political rights.

In the Gauteng High Court judgment of Economic Freedom Fighters $v$ President of South Africa (16247/14) [2014] ZAGPPHC 109 (11 March 2014), the issue involved as applicant the Economic Freedom Fighters (EFF), which was a newly-registered political party still finding its feet financially and administratively. The EFF had asked the IEC, the first respondent, to waive the deposit fee for the 2014 national and provincial government elections because the fee was unaffordable for the EFF. When the IEC refused to waive the deposit fee, the EFF approached the court for relief, asking among other things that an order be granted suspending the operation of the regulations regarding payment of the deposit. The applicant's arguments were based on the fact that, as a newly formed party, it did not receive the parliamentary funding available to political parties which had representatives in Parliament. The court held that it could not interfere with the determination 
made by another branch of government, the legislature, on the payment of the election deposit fee (para. 23).

This judgment demonstrates the fact that the requirement for an election deposit places political parties who are participating in elections on different and unequal footings. In this regard the political parties that are represented and receive funding from Parliament can easily afford to pay the election deposit, and therefore participate in the elections. On the other hand new political parties who are not represented and thus do not receive funds from the legislature may not participate in the elections if these parties are unable to afford the deposit fee.

The issue of the election deposit also arose in the context of local government elections in the Electoral Court judgment in the case of the National Freedom Party $v$ Electoral Commission (011/2016 EC) [2016] ZAEC 3 (5 August 2016). The National Freedom Party (NFP) failed to pay the election deposit fee on the prescribed date. Consequently the NFP was not registered by the IEC as a party to contest the national municipal elections because it had failed to pay the deposit required in terms of the law. The NFP approached the Electoral Court for relief against the decision of the IEC which, it was alleged, had declined to exercise its discretion by refusing to extend the time period in which the NFP could pay the required deposit. In dismissing the application of the NFP, the court held that there was no provision in the legislation that enabled the IEC to grant an extension to anyone regarding that person's non-compliance with the law (para. 20).

As was the case with the African Christian Democratic Party (para 23), the interpretation of the electoral law should seek to promote enfranchisement rather than disenfranchisement and participation rather than exclusion. Arguably, the court in the National Freedom Party case failed to interpret the provisions of the Municipal Electoral Act in a manner seeking to promote democracy. The NFP is a well-known national political party. It was represented in many municipalities and was also a governing party in at least two municipalities in KwaZulu-Natal prior to the 2016 local government elections; in the final list it has six seats in the National Assembly, and six seats in the KwaZulu-Natal provincial legislature (Parliamentary Monitoring Group 2014). Moreover, there is no dispute that the NFP intended to contest the local government election, but only that it erroneously paid the deposit after the deadline for the payment of such deposits. The court applied an inflexible and narrow interpretation of the law, arguing that the law does not grant the IEC the discretion to condone non-compliance with the deadline for payment of the deposit requirement. In the case of the African Christian Democratic Party (para. 31), it was held that in interpreting the provisions of the Municipal Electoral Act on the payment of the election deposit, the importance of promoting multi-party democracy and the political rights of citizens should be borne in mind. If the court had applied the guidelines of the Constitutional Court, the NFP could 
have been condoned for paying the deposit after the deadline, more particularly because there was no evidence before the court that any political party would have been prejudiced by granting condonation for late payment of the deposit fee. Consequently thousands of members of the NFP and other ordinary citizens were denied their democratic and political rights to participate in the local government elections owing to the rigid requirement for the deposit fee.

\section{General Position in SADC}

The election deposit fee cannot be isolated from the environment in which elections are held in SADC countries. The comparative overview in SADC countries indicates that, despite guaranteeing democracy and political rights in their constitutions, some of these countries still fail to adhere to the spirit of their constitutions. This offends constitutionalism and impinges on democracy. The question arises as to why these countries fail to uphold their constitutions. Although this question is beyond the scope of this study, some of the reasons could be attributed to the history of civil wars that took place in these countries after independence. Conflicts are normally characterised by a culture of defiance, lawlessness, and a lack of respect for human rights. Ndulo and Lulo (2010) reinforce this view when they point out that elections organised in post-conflict environments take place in a tense and high-risk atmosphere. They support this argument by pointing out that challenges involved in post-conflict environments arise from the decline in humanitarian, economic and other related attitudes that prevails during the conflict. The issue of the post-conflict dilemma is worsened by the culture of former liberation movements which fail to transform into political parties after independence. This conclusion is supported by Mapuva and Muyengwa-Mapuva (2014) who attribute the culture of intolerance and the failure of Zimbabwe to transform into a democratic state to the culture of Zanu$\mathrm{PF}$, which has failed to transform from being a liberation movement to being a political party. Even though the matter of post-conflict attitudes might influence the culture of flagrant disregard for the rule of law, it must be noted that SADC countries obtained their independence more than twenty years ago. They should, thus, have transformed themselves from post-conflict environments to stable democracies. In this regard the African Union (AU) has adopted a number of instruments to promote democracy in Africa, including the African Charter on Democracy, Elections and Governance of 2004. The objectives of this charter include the adherence by each signatory state in the AU to the universal values and principles of democracy and respect for human rights; and to enhance adherence to the principle of the rule of law premised upon respect for, and the supremacy of, the constitution and constitutional order in the political arrangements of political 
parties in each state. The effective implementation of this charter will enhance the promotion of democracy and the rule of law in Africa. In a practical sense west African countries have forced the former president of Gambia, who had lost in the elections, to transfer power to the new president who had won the elections (Atek 2017). The former president agreed to transfer power to President Barrow who won the elections only after west African countries threatened to remove him through military intervention. The action of these west African countries regarding the situation in Gambia demonstrates that the implementation of the AU instruments on the promotion of democracy will accelerate the democratisation of African countries.

\section{THE EFFECT OF THE ELECTORAL DEPOSIT ON DEMOCRACY}

The main focus of democracy in this study relates to the role of elections in democratising a country. Central to the procedure of democracy is the selection of leadership through competitive elections by the citizens (Barro 1999). Each country has its own set of procedures for the selection of candidates and election contests, which it claims to be based on its understanding of democracy. It is widely accepted that democracy is a commitment to government of the people, by the people, for the people (Catt 1999, p. 7). Catt argues that self-government and equal access are seen as vital components of democracy by those who aim at achieving political equality, and that the value of democracy lies in its provision of other desirable ends, such as the basic idea of equality. Accordingly, democracy is not an end in itself. When all people are seen as equals, this means, in terms of democracy, that all people must have the same opportunities to participate in the process.

Lack of access to the economy and the poverty that has affected developing countries in Africa has the potential to deprive people of equal access to participating in elections. This is because of the requirement of an election deposit as a qualification for candidates wishing to participate in elections. According to Statistics South Africa (2016) the rate of unemployment in South Africa in May 2016 was reported at 26.7\%; in Zambia it was 7.8\% in 2014 (Mujenja 2014); in Namibia it was 28.1\% in 2014 (Namibia Statistics 2014); and in Zimbabwe it was reportedly 37\% in 2014 (Zimstats 2015). These figures demonstrate that these countries have weak economies. The unequal treatment of rich and poor can be explained as an unequal access to election participation. This view is reinforced by left-leaning writers such as Catt (1999) who argue that candidates who feel inferior with regard to their incomes and jobs are not able to participate in the political arena on the same footing as those who have money (Catt 1999). This sentiment is also echoed by Maiko Zulu, an independent candidate for Kabwata constituency in 
Lusaka, Zambia, when raising his concern about the election deposit fee (Africa Fight Now 2016). He argued that the electoral process now seems to be a preserve of the rich, thereby commercialising participation in leadership. The argument against election deposit fees is reinforced by the high rate of poverty in developing countries. Accordingly, the deposit fee may not be appropriate for the economic level of the majority in the SADC countries.

The requirements for an election deposit have the potential to create and sustain an elite democracy in developing countries. Elitism is explained as the view that only a few are qualified to rule (Girvetz 1967). Girvetz further states that the term elite refers to any group set apart because of some superior quality or condition. Democracy, on the other hand, stands in contrast to rule by a particular group, for instance aristocracy, where a privileged class rules (Catt 1999). In a democracy, people who are able, favoured or preferred for reasons other than wealth or other privileges may govern. The deposit fee required in developing countries affected by inequality, their poverty and lack of a sound economy thus disadvantages aspiring candidates with regards to participation in elections. Consequently, this impinges on democracy.

\section{THE VALUE OF AN ELECTION DEPOSIT}

The popular view of the need for an election deposit is in order to establish the party's or candidate's serious intentions with regard to contesting elections, as elections involve huge costs for the state. This view is reinforced by the Chief Communications Officer of the Independent Electoral Commission of South Africa, Kate Bapela, when explaining that the purpose of an election deposit is to ensure that only parties of substance participate and that the threshold is intended to avoid frivolity in the electoral process. Accordingly, it seeks to obviate the possibility of a long ballot which raises the costs of printing to an unreasonably high figure (Geldenhuys 2013).

The purpose of the election deposit should be weighed against the value of political rights and democracy, and the context of electoral contests which are increasingly competitive. Electoral competition results in political parties spending exorbitant funds on the election. In this regard, in the 2016 South African local government elections political parties spent unprecedented amounts of money, with the African National Congress (ANC) spending R1 billion, the Democratic Alliance (DA) spending R350 million, and the Economic Freedom Fighters (EFF) spending R10 million (Hunter et al. 2016). Given the fact that funding political parties is not regulated in many countries, including South Africa, the uneven funding of political parties by private funders may put different parties in an uneven situation with regard to participation in elections. Parties that receive more funding are advantaged over those receiving less funding or no funding 
at all. Money has thus become an essential tool in influencing the success of election campaign.

It should furthermore be noted that those countries requiring an election deposit fee do not even fund political parties for election campaigns. The election deposit thus further disadvantages those parties which do not receive funding. They are not only disadvantaged by being unable to compete evenly with wellfunded parties, but are further excluded from participating in elections because of their inability to afford the election deposit. Given the history of the struggle for political rights and the attainment of democracy, citizens should not be denied these rights easily. It cannot be said that the election deposit fee is the only mechanism that could measure the participants' seriousness to contest elections.

The relevance of the election deposit has recently been questioned in developed countries. In this regard, the Electoral Commission (EC) of the United Kingdom (UK) is reported to have proposed scrapping the deposit fee for elections in the Rochester parliamentary by-election (Perraudin 2015). The EC described the requirement of an election deposit fee as unreasonable in that the ability to pay a specific fee should not be a valid criterion for determining access to the right to participate in elections. The commission suggested that instead of a deposit fee, a candidate should be required to gather the signatures of a set number of supports to show that he or she is seriously contesting an election. The report of the commission is important in demonstrating that there are other effective ways of alleviating the possible abuse of the election system by citizens. Moreover some countries in the SADC such as Angola and Mozambique successfully run their elections without requiring an election deposit.

The conclusion can be drawn that the election deposit fee creates a barrier for citizens wishing to participate in elections. This is evident from political parties in South Africa and Zambia who were excluded from participating in elections simply because they could not pay the election deposit fee.

\section{CONCLUSION}

The environment within which elections take place in most SADC countries indicates that despite the fact that they proclaim principles of democracy and constitutionalism in their constitutions, they do not adhere to these principles. The reported incidence of political violence and the election rigging results in some SADC countries indicate that the conditions under which elections are held are not conducive to democracy.

Elections are very important as they provide one of the main guarantees of democracy. Equal participation in elections democratises a country in that it minimises post-election violence and the unlawful overthrowing of the 
government. If elections are contested fairly, citizens are more inclined to unseat an unpopular government through elections rather than by violence. If the purpose of the deposit is to establish the party's or candidate's serious intent, the deposit is not the only criterion for achieving this purpose. The exclusion of the NFP (which is represented in the National Assembly) from contesting elections might indicate that deposit requirements may not be the sole criterion for determining whether a party can contest the elections. The party whose members and office bearers make a living by representing it in parliament, in provincial legislatures and municipalities, and whose internal machinery has not been reported to be dysfunctional, could hardly be said to lack a serious intention to contest the elections. Furthermore, it is evident from the EFF case that the deposit fee requirement might place political parties in unequal situations with regard to participation in elections because of affordability. New political parties that are not represented in parliament might thus be excluded from contesting elections simply because they lack a deposit fee. In this instance, the election deposit fee would be a rigid and inaccurate means of determining the party's serious intentions to contest elections.

The deposit fee criterion may not be relevant in all cases in determining the seriousness of a candidate with regard to contesting elections. In some SADC countries, such as Mozambique and Angola, there is no nomination fee or deposit fee. Yet there have been no reports of abuse of the system in these countries by individuals, or reports of political parties who lack the serious intention to participate in elections. In other SADC countries, however, political rights are still denied owing to the inability of candidates and candidate parties to afford the election deposit fee in a democratic dispensation. Accordingly, the conclusion can be drawn that the election deposit fee stifles democracy in developing countries.

\section{- REFERENCES -}

African Christian Democratic Party v Electoral Commission 2006 (3) SA 305 (CC).

African Union 2007, African Charter on Democracy, Elections and Governance, African Union, Addis Ababa, Ethiopia.

Angola 2010, Constitution of the Republic of Angola, [n.p., Luanda?].

Ateku, AJ 2017, 'High stakes as West Africa prepares military action against Gambia's Jammeh', SowetanLive. Available at http://www.sowetanlive. co.za/news/2017/01/19/high-stakes-

Barro, RJ 1999, 'Determinants of democracy', Journal of Political Economy, vol.107, no.6, pp. 158-183.

Botswana 1996, Constitution of Botswana 1996 (as amended up to 2006), Govt. Print. and Pub. Services, Gaberone. 
Catt, H 1999, Democracy in practice, Routledge, New York.

De Vos, P 2014, South African constitutional law in context, Oxford University Press, Southern Africa.

Dovey, L 2009, Africa Film and Literature: adapting violence to the screen, Colombia University Press, New York.

Economic Freedom Fighters $v$ President of the Republic of South Africa (6247/14) [2014] ZAGPPHC 109 (11 March 2014).

Electoral Institute of Southern Africa 1999, Namibia: presidential and National Assembly elections, EISA, Johannesburg.

Electoral Institute of Southern Africa 2008, Election Observer Mission report for Zambia presidential election, EISA, Johannesburg.

Electoral Institute of Southern Africa 2012, Report on the general elections of 31 August 2012 in the Republic of Angola, EISA, Johannesburg.

Electoral Institute of Southern Africa 2014, Observer Mission on Mozambique presidential, legislature and provincial elections, EISA, Johannesburg.

Electoral Institute of Southern Africa 2014, Election Observer Mission report on presidential, legislative and provincial assembly elections in Mozambique, EISA, Johannesburg.

Electoral Institute of Southern Africa 2014, South Africa: Observer Mission preliminary statement to the 2014 national and provincial elections, EISA, Johannesburg. Electoral Institute of Southern Africa 2016, South Africa: Observer Mission report for local government elections 3 August 2016, EISA, Johannesburg.

Electoral Commission v Hlophe 2016 (5) SA 1 ( CC).

Geldenhuys, H 2013, 'Small parties election too expensive', Independent Online. Available at <http://www.iol.co.za/news/politics/small-parties-electintoo>.

Girvetz, H 1967, Democracy and elitism, Scribner's, New York.

Greenberg, D, Katz, M, Oliviero, MB \& Wheathey S (eds) 1993, Constitutionalism and democracy: transition in the contemporary world, Oxford University Press, New York.

Hunter, Q, Mokone, T, Ndenze, B \& Jika, T 2016, 'Elections: it's a megabucks poll cliffhanger', Sunday Times, 31 July 2016. Available at http:/ / www.timelive. co.za/sunday times/news/2016/07/31/EI

Kham v Electoral Commission 2016 (2) SA 388 (CC).

Kriger, N 2003, Guerilla Veterans in post-war Zimbabwe: Symbolic and violent politics 1980-1987, Cambridge University Press, Cambridge, U.K.

Lindberg, I 2006, Democracy and elections in Africa, Johns Hopkins University Press, Baltimore.

Mapula, J \& Muyengwa-Mapuva, L 2014, 'The troubled electoral contestation in Zimbabwe', International Journal of Political Science and Development, vol.2, p. 17. 
Maletsky, C 2009, 'Namibia: ten parties forfeit election deposits', The Namibian 2009. Available at

< http: / / www.allafrica.com/stories / 200912080593.html.

Masunungure, EV 2014, “"The menu of manipulation"' and the 2013 Zimbabwe elections: towards explaining the technical knockout', Journal of African Elections, vol.12, p. 100.

Mujenja, F 2014, 'The employment statistics of Zambians perceptions', Afrobarometer, Briefing paper no. 135.

Mueller, DC 1996, Constitutional democracy, Oxford University Press, New York.

Mozambique 2004, Constitution of the Republic of Mozambique, [Impresa Nacional de Moçambique], Maputo.

Mozambique 2004, Electoral Law 7 of 2004.

Mozambique 1998, Electoral Act 73 of 1998.

Namibia 1990, Constitution of the Republic of Namibia, Ministry of Information and Broadcasting, Windhoek.

Namibia 2014, Electoral Act 5 of 2014.

National Freedom Party v Electoral Commission (011/2016 EC) [2016] ZAEC 3 ( 5 August 2016).

Ndulo, M \& Lulo, S 2010, ' Free and fair elections, violence and conflict', Havard International Law Journal, vol. 51, p. 162.

Norris, P 1997, 'Choosing electoral systems: proportional, majoritarian and mixed systems', International Political Science Review, vol. 18, pp. 297-312.

Parliamentary Monitoring Group, South Africa 2014, 'Elections seat in parliament'. Available at https:/ / pmg.org.za/page/ political party representation.

Perraudin, F 2015, 'Scrap the 500 deposit to run for parliament, says Electoral Commission', The Guardian, 13 January. Available at http://www.the guardian.com/politico/2015/jan

Shalala, P 2016, 'Zambia outrage as presidential nomination fees are hiked by 750\%', Africa Fight Now 2016. Available at https://africafightnow. org/2016/04/08/zambia-outrage

Schonteich, M \& Louw, A 2009, 'Crime and Justice programme', Institute of Security Studies, Occasional paper no. 49.

South Africa 1996, The Constitution of the Republic of South Africa as adopted on 8 May 1996 and amended on 11 October 1996, [Government Printer, Cape Town].

South Africa [1998?], Electoral Act (No.73) of 1998.

South Africa 2000, Local Government Municipal Electoral Act (No. 27) of 2000.

South African Development Community 2014, Preliminary statement of the Observer Mission on the Presidential and National Assembly elections of Republic of Namibia held on 28 November 2014.

Southern African Development Community 2016, Observer Mission to the 2016 general elections in the Republic of Zambia, [Lusaka]. 
Southall, R \& Van Zyl Slabbert, 2013, ' How and why Zanu-PF won the 2013 Zimbabwe elections', Strategic Review for Southern Africa, vol. 35, no 2. pp. 135-151.

Statistics South Africa 2016, Report 9 May 2016, Statistics South Africa, Pretoria.

Zambia 1991, Constitution of Zambia, [Government Printer, Lusaka].

Zambia, 2006, Electoral Code of Conduct Regulations Act (No 12) of 2006

Zimbabwe 2013, Constitution of the Republic of Zimbabwe, [n.p., Harare].

Zimbabwe National Statistics Agency 2015, 2014 Labour Force Survey Report, [Zimstat, Harare].

Zulu, M 2016, www.zambiareports.com/2016/02/05/ecz-election-fees-unrealistic-charges-maiko-zulu, accessed 4 May 2016 